\title{
Enzyme Activity Alteration
}

National Cancer Institute

\section{Source}

National Cancer Institute. Enzyme Activity Alteration. NCI Thesaurus. Code C40576.

Enzyme Activity Alteration involves a change in the quality of the existing state of

function of a biological molecule (usually protein, RNA, or DNA) that possesses catalytic activity. 